\title{
THE EDUCATION OF LOVE.
}

\section{By Sally Neill Roach, Loutsville, Ky.}

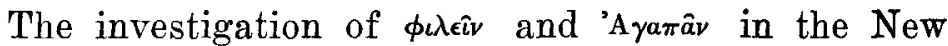
Testament opens to the student an intensely interesting and important question. Since, on account of its egoistic tendencies, philein* cannot serve, even though it is Christ-centered, and since, on account of its dominant and out-reaching nature, agapan, however deep and controlling, will not do the will of God unless it is Christcentered, by what means and when does the Holy Spirit accomplish the necessary training that shall fit the redeemed, not only for some assigned and special service during the earth life, but for an eternal and uninterrupted service during the life that is to come? The answer to this question as it is given in incident and character-picutre here and there on the sacred pages, unfolds the gracious and tender, and yet firm and decided manner in which God deals with the impulsive and uncertain philein and with the imperious agapan and evolves from both the deep-rooted, Christ-centered agapan that shall forever redound to the divine glory. Here is opened the wonderful subject of God's Permissive and Positive Calls. As the study of these progresses it becomes manifest that there is between them a marked distinction, though the distinction lies in the manner and not in the fact of the exhibition of God's sovereignty and grace. "Trust and Obey" is the watchword of the Kingdom, its simplest and its greatest lesson, in the mastery of which lies the only pathway of progress and the key-note of ultimate victory. In the Permissive Call God summons philein and deals with its self-interest and consequent lack of trust. In the positive call God summons agapan and deals with its self-will and consequent unwillingness

"For convenience, the Greek words will be written in English text. 
to obey. But it is one God who calls, and all those who are constrained to pass through the many and various experiences are made one in their service to Him.

It is a common mistake, and one that is productive of much confusion and error, to restrict what is mentioned as a "call from God" to a call to preach the gospel, or to do what is termed "religious work." But the Bible does not read in that way. There the tasks to which God calls His chosen vary as greatly as do the individuals who are called. Noah was called to build an ark; Abraham, to a marked pioneer movement; Moses, to the organization and command of a great host; Aaron, to the Priesthood; David, to the throne; Isaiah and Jeremiah, as messengers of the Most High to their own people; and Jonah, as a foreign missionary. In the New Testament, Zacharias was called to be the father of the Forerunner; Mary, to a life of suspicion and sorrow; Martha, to the high task of home-making; Joseph of Arimathea, to furnish a tomb for the Saviour, and, with Nicodemus, to place in it His body; Peter, to open the gospel-doors to Jews and Gentiles; Paul, to set forth the deep meaning of the divine message; and John, to give a vision of its coming glories. Shall the servant circumscribe or dictate his task? Surely, that servant errs who undertakes to adjust duties before God with respect to their relative importance, or to declare the spiritual rank of the servitors by the nature of the task assigned. The importance and the dignity of the divine call lie not in its purpose and outcome, but in its Source and Authority.

To the Old Testament we first go for a typical instance of God's dealings with philein through the medium of the Permissive Call. The first Temple is the typical instance. The difficulties that may be encountered do not seem to present themselves to the subject, or to be considered, if presented; but, the divine consent having been obtained, the work is at once undertaken. God deals very tenderly with His people. He knows His 
own, and He also knows that love is not wanting in sincerity because it is, as yet, untrained. When He grants the faith and hope that claim ownership in Himself and exult therein, He does not doubt or misjudge the untutored love that He intends shall one day confess His ownership in the redeemed. That David gave expression not only to the spontaneous desire of his own heart, but to the desire of Israel whom he represented, is manifest from the willingness and the abundance of the offerings (I. Ch. $29: 6-9)$ that were brought. Therefore, in the story of the first Temple we find that God, emphasizing the fact that such a thing had not been commanded, grants the Temple to Israel, though He appoints Solomon to accomplish its building; that, divine sanction having been accorded, wealth in lavish abundance, every facility and resource needed, and every outside help that was essential, was readily at hand to the forwarding of the work; and that the result was a production that was a marvel of grandeur and magnificence.

One sees the Temple completed and dedicated, and Israel, as a nation, beginning to feel more and more the burden of maintaining a pure Jehovah worship which had been so delightful in the Tabernacle in the wilderness and so essential amid the hostilities of the Conquest. Not one iota is the standard lowered to meet Israel's undisciplined love. Pure worship entails the stigma of peculiarity among the surrounding nations; it means abstaining from much in which it seems advantageous to engage, an inviolate line drawn where often these nations would court alliance and allure with their splendors; and it means Israel's restriction from much that is enticing, and Israel's bearing of much that seems onerous and useless.

Philein love is the expression of the pleasure of the subject associated with and derived from the object, and under such conditions as these no pleasure is perceived. The voice of philein is dumb, and that of the 
deeper agapan has not yet been awakened to utterance; and because Faith, Hope and Love are an inseparable trinity, Faith hides her head in Love's dark mourning robe, and Hope has not one word of encouragement to offer. The shrinking soul, in abject terror, says to God, "I can not!" The altar fires burn low; the Sin-offering and the Burnt-offering are not brought to the Sanctuary. There is no out-look of encouragement; resources have been exhausted. It is the period of utter and abject discouragement that must come to this impulsive (philein) love as before a faithful God it comes face to face with its own egoism and helplessness, and realizes its utter and absolute failure before that God to whom it longed to bring its treasures and the trophies of its triumphs. In all the story of human nature there is no dejection like it.

But there is another step in the tutoring of this (philein) love by the plan of the permissive call. Not only is the soul brought face to face with its own weakness and self-seeking, but now, stripped and humbled and confronted with the opportunities that were granted to its own importunate pleading, it is brought face to face with a God who, while wondrously gracious and patient and forbearing, is omnipotent and supreme, and jealous concerning the dignity and honor that are due to His holy name. In its humiliation the soul is taught that what this God permitted to be undertaken must now be accomplished, else the power evidenced in His permission would be subjected to question; that that for which He has supplied resources and opportunities must be achieved with just the means that $\mathrm{He}$ has supplied, or else $\mathrm{He}$ would be proven lacking in wisdom in adapting means to an end; that that which, by His sovereign permission, loomed up in forbidden antagonism must be met by the soul in the abandonment of trust, or else this were a God wanting in love to His chosen.

That wondrous (agapan) love of God awakens its own 
response, and to the chastened, humbled soul the "must," losing not one whit of its imperative nature, gradually becomes again a most gracious "may"-not the "may" having the philein interpretation that means the pleasure of the Ego, but the "may" with the agapan interpretation than which, to this same Ego, there can be no greater evidence of Grace or no more binding "must."

It is exactly to the first task, but under very different circumstances and understanding its much deeper meaning, that the soul is now made to return. Henceforth it is of far more importance to the Subject that he should comprehend God's purpose in fostering the first desire, and should become acquainted with God's will concerning him and his work, than that God should be informed of his wishes with reference to that work and the aids deemed necessary to its completion. Moreover, these same opportunities and aids must now be such as will most glorify God, rather than make easy or safe or unhindered the task.

There is in all God's word no more wonderful record than this divine dealing with philein through the agency of the permissive call-plilein, Christ-centered for all eternity in regeneration, Christ-centered for time in the permitted offer of service, and yet, as impulsive, vacillating and unreliable as a winsome, affectionate, untutored child, or as an ardent, enthusiastic, undrilled soldier. But God permits nothing to be undertaken by philein that His wisdom will not justify and His omnipotence bring to completion. Therefore, as philein emerges from the task-enforced discipline, still more thoroughly Christ-centered, but transformed into the Self-forgetting agapan, we see the thought of the soul's ownership in God lost in the greater and deeper thought of God's ownership in the soul, and that which was weak through impulsiveness and desire for self-preservation and selfgratification is made strong in the utter abandon of trust. 
Under the patient, persistent training of the Holy Spirit "the love" emerges from its philein period, and with attention fixed only upon the Master.

That this permissive call, when granted, is a manifestation of the purpose of God, and is therefore certain to be enforced in the fulfillment of His will, is emphasized by the fact that God does not always permit the undertaking of the task that is suggested by the subject, but sometimes imperatively withholds His approval, and sometimes positively assigns another task instead.

Moreover, it must be borne in mind that there is a vast difference between God's permissive call whereby He approves a proffered request and grants the divine sanction for the carrying out of a proposed plan, and $\mathrm{His}$ permissive decree wherein, being unconsulted, He hides His face and withholds restraining grace, that His people or His enemies, following the bent of their own inclinations and becoming entangled in the consequences thereof, may be the more thoroughly brought, the one to repentance, and the other to overthrow. In both the thought of permission implies some granted desire of the creature. In the call this desire is granted by approval; in the decree, by forbearance. In the one, the desire of the creature, although sifted and purged, will be ultimately proven to be God-directed, will be trained, stimulated, and more than fulfilled. In the other, the desire of the creature will be clearly shown to be contrary to God's will.

The building of the Temple and the martyrdom of the Apostle Peter are examples of God's permissive call. Hezekiah's friendship with Babylon (II. Ch. 32:31), Pharaoh's persecution and pursuit of Israel (Ex. 14:17-18) and the world's active hostility to the saints are examples of God's permissive decrees.

In the study of philein and agapan it has been shown that philein is the declared, spontaneous and impulsive assent to an ownership from which comes a realization of protection or pleasure; while agapan is the declared, 
voluntary and persistent consent to an ownership from which comes a realization of responsibility or subjection. As a dominant sentiment in the human heart, this loving (agapan) crowns its object, whatever that may be; obeys the will which demands for this object a fixed attention; holds in firm subjection all other pleadings of Self; assumes all responsibilities imposed; counts no cost; spends and delights in being spent in the service of the controlling object or idea. So Alexander the Great surrendered himself to conquest; Napoleon, to glory; Columbus, to discovery; and Darwin, to science. So many a man has surrendered himself to his one masterpassion which asserts complete domination over Self. Whatever it may be that becomes the object of this absorbing (agapan) love, efficiency in service thereto becomes of the love its distinguishing mark, as inefficiency at the crucial moment is distinctive of the childish philein; for in agapan the will asserts its regnancy, and, the more there is to distract and oppose, the more voluntary and fixed is the attention. It is not difficult to understand that this masterful loving (agapan) in the heart of a man, by the very positiveness of its nature, demands very positive dealings that it may be concentrated upon the Christ, and may serve Him only. It does not need to be changed in kind, but to be subjected to a new Master who must be recognized in both temporal and eternal things. It has already learned to surrender every thing to the controlling voice in an utter abandonment of trust; it must be taught the absolute mastery of the new Voice that speaks, and must be constrained to yield an implicit and voluntary obedience to that Vioice alone.

In the Old Testament, the call of Israel to conquer Canaan stands out as the typical instance of the Godcentering of this (agapan) love through the agency of the imperative call; and in the New Testament its parallel is in the call of the arch-persecutor, Saul of Tarsus, to be the Apostle Paul, henceforth the "bond-slave" 
of the Lord Jesus Christ. In each instance it is manifest that the first suggestion of the proposed service came to the subject with the force and emphasis of a positive command. Israel, exultant in recent deliverance from bondage, enthused with the idea of becoming a great nation, and therefore gladly submissive to every requirement that would secure organization and progress, was confronted with a command to which obedience was black with threatenings of national extermination; sharply and squarely the issue was drawn between the desire for national advancement and present allegiance to the divine purpose. Saul of Tarsus, on fire with zeal for the preservation of the religion of the Jews and the earthly glory of his people, was called upon for an entire reconcentration of his faculties and a re-direction of his energies and attention to an aim that seemed to him antagonistic to all for which he had labored. And in each case the new issue was put with all of the tremendous emphasis of a divine "must." To Israel at KadeshBarnea, and to Paul on the way to Damascus the abruptness of the change demanded was bewildering, and the difficulties overwhelming; but in each case stern manifestation of the divine power enforced the word of command. Israel, in the forty years of wandering in the wilderness, learned that Jehovah's "must" was no trifling matter and that disobedience was the surest way to accomplish national extermination; and Saul, blinded by the glories of the exalted Jesus, during the hours of darkness and bewilderment and pain, came to understand that Heaven's sceptre was held by no impotent or uncertain hand. Before either task was begun the Spirit did well $\mathrm{His}$ conquering work, and the subject had learned not only the authority but the un-dreamed-of grace that was vested in this compelling power, and was taught to desire above all things to know and to do the divine pleasure. This time-limited, self-directed love-albeit, agapan-hitherto bent to the service of self-enthroned 
ideals, had been arrested by Omnipotence and warmed by the in-breathing of Divinity into the time-forgetting, selfout-pouring consecration that would count it highest joy to serve God alone, and to the chastened subject the Lord's imperative "must" had become a marvelously gracious "may." Israel of Kadesh-Barnea had lost nothing of national enthusiasm, when, stepping down into the bed of the Jordan, it became Israel of the Conquest; and Saul of Tarsus abated nothing of his singleness of purpose or of his tireless energy when he became Paul, the Apostle, and stlyed himself the "bond-slave" of the Lord Jesus Christ.

There is one respect in which the positive call of the Apostle Paul differs from the positive call of the Israel of the Conquest, though the difference does not in the least affect the nature or the manner of the call. This difference relates wholly to the time at which the call was given and brings into further emphasis a mark distinguishing the positive call from the permissive. The call of Paul to the apostleship was simultaneous with his acknowledgment of the divinity of the Nazarene, and ever afterward was to him inseparably connected with the conviction that revealed himself as a sinner and the persecuted Jesus as the only Saviour. This is often so. Many a man has desperately fought conviction of sin from a deep and unexplained realization of the fact that confession would inevitably demand not only a thorough and radical change in the whole tenor of life-which change would be gladly yielded in the acknowledgment of Christ as Saviour-but also a specific abandonment of some cherished plan or purpose, in itself not at all wrong, and the adoption of some other course in life, whose adoption must mean the confession of the Christ as absolute Master in immediate and fundamental detail. To Saul of Tarsus to confess the Christ as the long-expected Messiah and his own personal Saviour meant an overwhelming obligation to preach Him. And no matter how 
humbly and consistently he might have lived, no matter how clearly (in his chosen vocation as a Jewish lawyer) he had set forth the higher law of the gospel, no matter how faithful and patient and true had been his personal appeals in private life, that obligation, as he then faced it, could never have been met outside of preaching.

One can not fail to perceive that in contrast with the vehement desire that is the characteristic of the earlier stages of the permissive call the earlier stages of the positive are marked by the strength and depth of accompanying convictions. The conditions to be met stand out with startling clearness; no item is left unnoticed; no difficulty is glossed over; no obstacle or hindrance is concealed. But every harsh detail spells the divine "must" and drives it with conquering power deep into the soul. As the call progresses, no matter how great or how small the task, it becomes to the soul the intensely important matter for the prosecution of which life itself is given. These are convictions that may not be gainsaid, that carry with them the courage through which they find expression, and the resolution and patience that are necessary for their full manifestation. Witness the Apostle Paul, as, fronting the threatenings and oppositions that awaited him at Jerusalem, he calmly declared: "But none of these things move me, neither count I my life dear unto myself, so that I might finish my course with joy, and the ministry which I have received of the Lord Jesus, to testify the gospel of the grace of God." The man who before God is convinced that he must is the man who before men will prove that he both will and can: and therefore, who, against all odds, will win for himself and his cause both confidence and esteem. Moreover, this conviction of the impotent personality of the servant and of the supreme personality of the Master, that were born with the birth of the call, together with the conviction of increasing and imperative obligation, growing with the growth of the call, and manifesting 
themselves in continued action and endeavor, are not less marked than the later conviction of God's wonderful grace in rendering thus emphatic every conviction accompanying the call. This last conviction now translates the earlier "must" into a marvelous "may" whose deep convicting power emphasizes the "private law" of the inestimable privilege that it reveals. It is the purpose of both the positive and permissive calls to arouse and stimulate in the heart that Christ-centered, steadfast

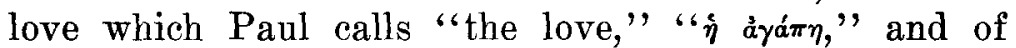
which he writes: "The love never faileth." Therefore, there can be no greater blessing granted to a man than a deep and abiding conviction of the Master's claim upon him for some specific service, no matter how heroic are the measures that are required to awaken such a conviction. It is always the man who is conquered by an idea who will conquer with that idea. Even so, it is the man who is thoroughly conquered by "the love"" $\dot{\eta} \dot{a} \boldsymbol{\alpha} \dot{\boldsymbol{a}} \eta$ "- of Jesus, who will conquer for the Christ.

"The love" is born of God, and the infinite only can be its goal. The aim of victory in its unfolding is not merely the winning of new laurels, but the development of the conqueror for yet fiercer battles. The purpose of service is not the benefit of the Christ who is served, for the Infinite can not be benefitted by the finite, but the training of the servant that he may reflect the Nature of which he is made a partaker. In the present life, the soul-though redeemed-is yet bound by "the body of this death." Necessarily, then, the education of love must be marked by shocks and severities and by many a "face to face" meeting in many a desolate "wilderness." But this education is far too important in the eyes of the Great Teacher for its beginnings to be postponed until the tranquilities of heaven. Nay, verily, these very adversities are to minister to its progress; until, in the life to come, when each of the redeemed is presented "faultless"' before the throne. Then, unchecked and unhindered, 
shall the education of love be carried on to its constant attainment of more and more perfect service throughout the endless aeons.

The Holy Spirit knows thoroughly those whom He graciously brings to the heavenly birth. He knows their characteristics and traits inherited through the flesh, and He knows also the place designed for each and the precise service to be required from each in the eternal kingdom of the Lord Jesus Christ. Moreover, being infinite also in wisdom and in "the love," He never errs in the dealing that is necessary to bring each one to the accomplishment of His eternal purpose in order that the crucified and risen Jesus may be eternally glorified in each one of the redeemed. 